\title{
Three Early Historians of the American Revolution
}

\author{
By Fryderyka Kalinowska
}

The earliest histories of the American Revolution written by its contemporaries were born of the »Battle of the Quills» - as John Adams termed the ideological conflict fought out by American and English leaders and writers in the period between 1763 and 1776. That battle attended all the events that estranged the colonies from the mother country from the close of the French and Indian War up to the Coercive Acts, the Continental Congress, Lexington and the Declaration of Independence. It included petitions, letters of correspondence, statements, speeches, and articles in the colonial and English press, bur primarily it was a »war of pamphlets,.

The argument was »for» and »against» the American cause. As the oonflict grew older with the dozen years it lasted, the pamphleteers had to recapitulate the course of earlier events to sustain their arguments. This gave, naturally, birth to shorter or longer histories.

Another source of the early works on the American Revolution was histories of the particular colonies or regions which widened their scope with the developing tension between America and the mother country to cover a more general field. Their authors were also partial to one of the contending parties, to the American colonies or to England.

The answers to the »whys» and »hows» concerning the origin and character of the Revolution - for I should like to stress that these issues, the origin and character of the Revolution, were and have remained the principle questions asked bouh by the pamphleteers and contemporary historians - had to be couched in terms of »right» and »wrong». There came also the »if in history» - to use Sydney Hook's expression - i. e. the problem of what would have happened if the statesmen on both sides of the Ocean had pursued 
a different policy and of whether the war and American independence were a necessary or »inevitable» outcome of the previous colonial situation and the Revolutionary developments. But reflection on this latter question required a cooler, or perhaps more impartial approach. This would be the middle course between $\gg$ for» and »against», which - as I believe - may be detected rather early. The medium line was necessarily a less natural phenomenon and the attitude of the moderates was also coloured with some kind of parti pris.

Just at the disputes on the eve of the war, their importance and heat had given birth to the sbattle of the quills,» so the struggle for independence itself and the rise of an independent American republic became at once a great subject for historians. We have, therefore, quite a few early, English and American, histories of the American Revolution.

The subject was great but the wealth of these books lay mostly in a matter of numbers. They compare poorly with the depth of thought and incisive style so peculiar to the pamphlets, orations or even public documents of the agitated era of 1763-1776. They also hardly bear comparison with the later development of American political and social thought expressed by the documents and writings which accompanied the adoption of Federal Constitution, i. e. »Federalist.» As known, the American Revolution would not find its Voltaire, Hume or Gibbon either in the $18 \mathrm{th}$, or in the beginnings of the 19th century. Only a few of the score have proved their worth and found recognition. At the beginning of our own century their number was further reduced as almost all of them were accused of plagiarism in regard to one and the same contemporary English chronicle, The Annual Register.

In spite of this, some of the early histories deserve attention. They deserve attention not only for their values as such, but also for the reason that they marked the beginning of a certain pattern followed long after by American - and English - history. It is a pattern peculiar not only to the historiography of the American Revolution, but also to the literature of other historical events of similar magnitude or national significance, born also of their »battles of the quills» such as, e. g. on French Revolution, the partitions of Poland, Napoleon (Pieter Geyl - For and Against), etc. 
From among the six or seven histories usually recognized as interesting contributions to almost »current» historical writing, three very representative and important works have been chosen here for discussion.

Their authors were either active participants of the events or at least directly affected by them. It need not be emphasized therefore that regardless of how thruthfully each of these writers treats the related facts, their work reflects the authentic opinions and feelings of both loyalists and American patriots engaged in the cause at issue. They are as follows:

Thomas Hutchinson, The History of the Colony and Province of Massachusetts Bay (Vols I-II, Boston 176467), vol. III, publ. in London 1828, but completed in 1778.

Mercy Otis Warren, History of the Rise, Progress and Termination of the American Revolution, Interspersed with Biographical Political, and Moral Observations, Boston 1805.

David Ramsay, The History of the American Revolution, Philadelphia 1789.

Hutchinson was actually the first to finish the manuscript of his third volume. This was the volume covering the Revolutionary period and it was completed in 1778, although issued in print 50 years later. According to its title it refers to one province only. The previous volumes go back into the past. But the third, covering the period from 1750 to 1774 , is generally treated as one of the most important histories of the American Revolution (at least of its origin and opening years) with regard to the revolt of all the thirteen North-American Mainland colonies, and this for several reasons. It deals with the time of the gathering conflict with the mother country. Massachusetts and her capital, Boston, became the arena of the most spectacular contest; it was on Massachusett's soil that the actual hostilities began.

This history also occupies a place apart because it is treated as a sourcebook. There are at least two other loyalist histories of note, Peter Oliver's (chief justice of Massachusetts) and Thomas Jones' (justice of the supreme court of New York) who held similar views 
and expressed them in a much more virulent- language. However their books do not match Hutchinson's work and they were much less prominent than Hutchinson not only in historical writing, but in history.

It is known, but for clarity's sake should be repeated in this context, that Hutchinson had held very high public posts in the province from 1718, had taken part in the Albany Congress, was lieutenant governor, chief justice, and finally governor of Massachusetts from 1771 to 1774 . As chief royal officer of the most rebellious of the thirteen colonies, he led in person, on behalf of king and government, the almost daily dispute with the radicals for the economic advantages of the mother country, which he shared, and for the power of Crown and British parliament over the colonies, in which he loyally believed. So we have an almost current history written by one of the principal dramatic personae.

In addition to his daily public routine he also became the hero or victim of such well-known incidents as the Boston Stamp Act riots, when his house was almost demolished and his papers and manuscripts destroyed or damaged, so that his »History» became part of history: The affair of his semi-private letters to Thomas Whately, former secretary to George Grenville in London, in which he advised that colonial liberties should be abridged, and on which Franklin somehow laid his hands. He was also one of the originators of events of great moment which led to the Boston Tea Party of December 1773.

Being an American colonist and a merchant, he was against the Currency and the Stamp Act and even tried to persuade the government in London not to impose them. Being a loyal public servant of England, he firmly believed in the supreme power of Parliament and colonial duty of obedience. Once the laws were on the statute books, he naturally minded their enforcement; redress could be sought by legal means such as petitions. Meanwhile a revolt broke out.

The bitterness caused by popular hostility which he believed was undeserved, the fact that the Boston riots had been a blow to his property, to his intellectual achievement and personal security, all these factors taken together must have had no small effect on his further attitude. The events of 1765 most probably became a turning 
point in the fate, activity, and opinions of Hutchinson, just as they were a turning-point in the fate of the colonies.

$\mathrm{He}$ describes the developments, mostly political events and legal problems, with fair accuracy (knowledge and documents) and the utmost possible restraint of a well-bred gentleman and historian conscious of his calling (he was a New England Puritan), but, of course, as seen through his own eyes. His History is somewhat different in form from his public statements and private or semiprivate letters. In the speeches he indulges in longer and more rigid, formal exposition, in the letters - in more sincerity. But as to the gist of the matter, Hutchinson the historian voices the same opinions as the crown officer in public and the loyally-minded colonial in private.

If we were then to ask how Hutchinson envisaged the character of the Revolution and what he regarded as its causes, there are two sets of reasons of a different nabure.

We have first to go back to the close of the Seven Years' War. To Hutchinson's mind the war had been entered by England in defence of her colonies in North America from the Indians and France. Hutchinson points out that the colonists, and especially those of Massachusetts, were not only satisfied but simply carried away with joy over the British victory and salvation of America from the threat of France. Nevertheless, he later realized that those in England who had feared were right, namely that the first visible signs of aiming at independence, once Canada was freed from the French, could be detected soon after the war. In December 1773, i. e. a decade later, he wrote in a letter to Dartmouth:

»Before the peace (of 1763) I thought nothing so much to be desired as the cession of Canada. I am now convinced that if it had remained to the French none of the spirit of opposition to the Mother Country would have yet appeared, I think the effects of it/that is, the cession of Canada/worse than all we had to fear from the French or Indians.» ${ }^{1}$

1 Quoted by L. H. Gipson, The Coming of the Revolution, New York, 1954, p. 215; L. H. Gipson, The Great War for the Empire, in: The American Past, Conflicting Interpretations of the Great Issues, New York, 1961, v. I, p. 76. 
In his History Hutchinson also describes certain notes of reserve in the thankful messages of both houses of the Mass. General Court to Britain of that time. They stressed the contribution of Massachusetts to the war, the blood shed in battle then and for a hundred years before by her citizens, and the mutual advantages of the province and mother country. People became more and more jealous of greater British privileges than colonial rights, started to use the terms "whig" and »tory", which had not been current before, the term »tory» - thoroughly misunderstood by the common people being derogatory and aimed at labelling royal officials as bad. And hints at independence were looked upon with favour. ${ }^{2}$

So we can see that as to the origin of the Revolution Hutchinson points to certain changes in the general situation, at least in the temper and mood of the population after the victory over France, implying a feeling of strength which was expressed in dreams of a mighty, future empire on the American continent. This was also connected with the enormous increase of population as well as growing wealth, particularly that af Massachusetts.

Thus, Hutchinson was not blind to the broader circumstances and the deeper roots of the later rebellion. However, such remarks are carefully weighed and provided with a number of reservations: the powerful American empire was a distant dream, and - most important - the people were genuinely satisfied.

Another strand, much stronger, runs through the whole exposition. The new situation, the changes in mood and temper, vague and insignificant - since people always grumble under any government, especially when they are not the $\gg$ Ins» but the »Outs» - were not of enough importance as to justify logically the later rebellion.

Not under any government in the world, argues Hutchinson, could the people of Massachusetts be happier and better off than under British rule ${ }^{3}$ - they had broad self-government, enjoyed broad liberties and even some greater advantages than the people of Britain herself, e.g. they drank cheaper te a than the English (we know what a cup of tea and its price mean in the Anglo-Saxon world; it compares with ship money and taxation and later developments in

2 Thomas Hutchinson, The History of the Colony and Province of Massachusetts Bay, L. S. Mayo ed., v. III, Cambridge, Mass., 1936, pp. 60-61, 75.

${ }^{3}$ Ibid, pp. $251-253$ 
the colonies did show that it had much in common with both.) To return to the reasoning of Hutchinson: the people's welfare was such that they could not really want independence from the mother country who protected them and to whom they were sincerely and proudly attached. Other reasons must have incited them.

And this is stressed all through the book. It was the men greedy of public office, it was their private interests, their demagogy, their incitement that lay at the roots of and led to rebellion. The chief troublemakers were the Otises and the Adamses. The first had been early 'enemies: the elder Otis aspired to the office of chief justice of the province, which Hutchinson, being already lieutenant-governor, obtained, thanks to governor Bernard. They were inflamed, as he writes, with hatred of him personally and of the mother country generally. He implies that they wanted positions and advantages for personal advancement. ${ }^{4}$ Mercy Otis Warren, sister of the famous James Otis, tells us the story of that rivalry in quite the opposite way. To her, Otis was the immaculate patriot and hero, and Hutchinson was the evil one. Yet the principal inciter in Hutchinson's story, the shrewd, unscrupulous troublemaker aiming to overthrow the government and achieve independence for Massachusetts was Samuel Adams, embezzler of public funds and slanderer of royal servants. He recognizes, though, that Samuel Adams worked for popular liberty and adds that in his sparty» the end justified the means. ${ }^{5}$

The theme of well-being and paradoxical gathering of disorder through agitation and dark scheming is elaborated by Hutchinson at length. Since the early seventies only a small duty on tea had remained and almost all grievances were ramedied; it was quite unreasonable to rebel. And yet the assembly and town meeting, controlled by the group of evil troublemakers claimed more and more power, finally regarding themselves as equal to Parliament.

An illegal but efficient network of correspondence, agitation and propaganda was created for the demagogues' ends, a scheme full of secret and ominous implications. Gentlemen were less and less frequently met with common civility, and the Governor kept his title, but it was »a word without meaning to it».

${ }^{4}$ Ibid. pp. 63 ff., 182

${ }^{5}$ Ibid. pp. $211 \mathrm{ff}$.

${ }^{6}$ Ibid. p. 326 
It may be seen that if later historians were not sure, Hutchinson at any rate had no doubts that there was a revolution.

The respectable and sensible citizens, having no reason to resort to violence and seek independence, could be convinced only by "groundless fears of a future, imaginary evil.,. Hutchinson believed in limited orderly liberty, in which the élite ruled and thought for the people. Independence meant republicanism, which was equal to democracy, and that in turn spelled anarchy and further threats to society.

On the other hand, the connection with England secured not only law and order. The well-being of the colonies was unthinkable without her protection from the Indians and the Fnench, not least in the international sense, in war and on the sea. England had done so much for her colonies that separation, »in a moral view, could not be justified. He says so literally and he means it. ${ }^{7}$

There is an exposition in his History which sounds as if it were aimed at convincing those respectable citizens. He finished his third volume during the war, hoping for reconciliation, and did not live to see the end of hostilities. After stating his moral reasons and the familiar financial reasons (justifying Britain's need for money to ensure colonial security after the French and Indian war) Hutchinson comes forth with a much less usual consideration: do the few remaining grievances justify rebellion and make the war effort worthwhile? Then he makes the following points:

- Armed resistance would most probably be unsuccessful;

England would crush the revolt »with a stroke.))

- War would cause the death of many and misery and want for those who would survive; it would bring in its wake an enormous corruption of morals. And finally:

- Even if the colonists were to win independence, what next? A few unscrupulous leaders would take power and obtain personal profits, but the people would never again be so well off as under the rule of England. ${ }^{8}$

This passage in his History is little known. Whether he had a point there or not (before the event, i. e. before final American success, he could have had) he seems to have belived in what he wrote.

7 Ibid. p. 254

8 Ibid. pp. $254-255$ 
Other early historians, just as the politicians and pamphleteers, also believed in the evil role of instigators (or said so); in Hutchinson's case one could only ask how it happened that such demagogues and agitators appeared in practically all the colonies at the same time, used the same methods, and even set up a common and rather efficient - as he says himself - if not quite legal intercolonial correspondence and some kind of organization. So the underpinning of their work must have existed.

The epilogue which the story of the last civilian governor of Massachusetts had in England after his departure, at his own request, in the middle of 1774, was somewhat different from the role he played before and from the stand he took in his History. There he tried to persuade the king and government to mitigate the harch coercive measures against the colonies, somehow to avert the threat of war, and later to help reconciliation. But to no avail. It was the opposite of what he believed when in Amerika, namely that England was too soft and did not support with a firm enough hand her own public servants. Homesick for America, with the fresh image of revolting countrymen in his mind, seeing them from a new angle and knowing tham better than the English ministers, he could not convince the latter that their policy was wrong. That Massachusetts Yankee at King George's Court cut an awkward figure in his new surroundings.

No one else but John Adams was later told in London, how Hutchinson always felt his pockets for letters from his brother Foster in Boston, trying to read them and tell the King about the worsening situation in the colonies. He was humiliated by the King, who turned away, pretending not to notice him; he was ridiculed by the courtiers. ${ }^{9}$ This newcomer from America was in the literal and figurative sense a man from a different world.

Nevertheless, when the Declaration of Independence was proclaimed, he wrote in October of that same year, 1776, a diatribe against its »false and empty claims.» He remained a royalist to the end. It must never have occured to him that his countrymen were acting not only from fear of a future evil, but in quest of a future

9 M. C. Tyler, The Literary Hist. of the Amer. Revol. 1763-1783, New York 1897, v. II, pp. $402-403$ 
good. Be that as it may, Hutchinson in London is perhaps the very illustration of the gulf already at that time separating aristocratic England from America.

Hutchinson and his work have been of utmost importance in American historical writing. Both the portrait of Hutchinson as man and politician and the assessment of his 3rd volume (the first two being indesputably valued almost as sourcebooks) varied depending on the changing interpretation of the revolution itself. There is no space to go into that question in the present paper.

As far as contemporaries and early historians are concerned: to Sam Adams Hutchinson was en enemy of the people, to Franklin a traitor of his native land. To Mercy Otis Warren, author of one of the other important early histories of the Revolution, he was both an enemy and a traitor. He was - to use the words of Moses Coit Tyler - $\gg$ the head-devil of British tyranny in America.,

Mrs. Warren's history, although published in 1805, was written during the Revolution, under the direct impact and in the hot atmosphere of the events. She voices her opinions and writes her comments with the ease of an eyewitness and to some extent also participant of the great struggle, addressing the reader directly.

It should be stressed here that Mercy Warren was the daughter of the elder Otis, who, as a rival of Hutchinson's, had aspired to the office of chief justice of Massachusetts. She was also sister of James Otis, the famous champion of natural rights, and wife of James Warren, a revolutionary organizer of committees of correspondence and later speaker of the state House of Representatives. One of the many notes about her which John Adams left in his writings defines her as »Madam Mercy Warren, the historical, philosophical, poetical, and satirical consort of... General James Warren of Plymouth».10 She knew many a prominent political thinker and statesman, such as Jefferson and Washington. She also had a close friendship with Abigail Adams, wife of John. So the parentage and very environment of Mercy Warren account sufficiently for her strong patriotic feelings and violent animosity against the advocates of the rights and policy of England.11

10 John Adams, Works, v. X, p. 99

11 M. Kraus, The Writing of American History, Norman, Okla, 1953, pp. 7881; The Cambridge Hist. of Amer. Liter. New York 1946, pp. 217-218; Liter. 
An earlier expression of her view on the Revolution, its heroes and negative characters may be found in her satirical dramas written in 1773 and 1775. Evidently disregarding the Protestant and especially Puritan disapproval of the theatre, Mercy Warren was among the very first American playwrights and probably the first to introduce the satirical-political play into American Revolutionary literature.

In the present considerations these dramas are introduced for a particular reason. They help to bring out more strongly certain traits of her later history and also a question of historical interpretation. The views of the author may be seen in these plays in sharper focus than in her history, and at the same time they give her outlook in a narrower scope.12

The plot of her first play, »The Adulator», shows the revolutionary events in Boston in 1770--73, the people and its brave leaders in conflict with representatives of the crown. The names of persons and places - as in nontheatrical satires - were fictitious, but their actual meaning easy to guess. The scene was laid in an „Upper Servia» the American characters bore similar Roman names as they signed their polemical articles and pamphlets, (Brutus, Cassius) and the Governor was Rapatie. Hutchinson, to whom the author gave that ugly name, robs the colonies of their wealth to enrich himself, and not only revels in power, but finds satisfaction in the harm done by his men to the people. (» What throbs of joy! Nero, I tower above thee!» exclaims the tyrant in Mrs. Warren's play.)

The second play, entitled »The Group, appeared in 1775, when the civilian Governor had left Boston and his place was taken by General Gage. Here the villain was Hutchinson's brother, Foster. Mrs. Warren did not know that he wrote varning letters on the state of the province to London and that the ex-governor attempted in vain to convey their contents to the king. In this play Silla - or Gage - had pangs of conscience for being obliged to break the

Hist, of the United States, R. E. Spiller et al., eds, New York 1966, pp. 133, 186.

For the very comprehensive excerpts from Mercy Warren's History, a rare book almost unavailable in Europe and quite inaccessible in Poland, as well as for other valuable material I am indebted to the generous helpfulness and friendship of Mrs. Lucia Jaeger of the Public Library in Boston, Mass.

12 The contents of these dramas, very rare prints, are most exhaustively reproduced by M. C. Tyler, op. cit. v. II, pp. 193-196. 
resistance of the brave colonists who were fighting for freedom. This is an expression of the current feeling of Mercy Warren and the colonists that the British, representing their own country's interests, could be excused and perhaps even respected whereas colonial loyaltists were only deserving of contempt. It is a feeling carried over into the History, as may be seen later.

Mercy Warren's fancy for literature left its mark on the History. Her prose has often a poetical tint. The double motto is taken from Shakespeare and - St. Paul. As to the interpretation of the origin of the Revolution in her history the first layer - if we may call it so - does not differ substantially from the views expressed in the plays. The work is composed of 3 volumes, covers a wide range of developments and is full of discursive rambling. The Hutchinson of Mrs. Warren's History is the same Rapatie shown in her earlier play, »He was dark, intriguing, insinuating, haughty, and ambitious, while the extreme of avarice marked each feature of his character. His abilities were little elevated above the line of mediocrity, yet by dint of industry... he became master of the accomplishments necessary to acquire popular fame.» She says that in addition to the English common law he sdiligently studied the intricacies of Machiavellian policy ... he had seized the opportunity to undermine the happiness of the people while he had their full confidence, and to barter the liberties of his country by the most shameful duplicity.» ${ }^{13}$

But the head-devil of the $\gg$ Adulator» was not alone. His role was typical of the royal officials, especially those born and raised in the colonies. She calls them sprostitutes of power nurtured in the lag of America.,

George 111 was »steeped in exaggerated notions of royal prerogative and dazzled with the vast expanse of territories at the beginning of his reigns, he scould not stand opposition, and on the advice of his preceptor Lord Bute, corrupted Parliament to such an extent that it became an obedient instrument in his hands. Whereupon he easily overstepped the boundaries set to his power by the Constitution. I-Ie found a ready response with royal servants

${ }^{13}$ Mercy Warren, History of ... the American Revolution, ..., Boston 1805, v. I, pp. 90-91. 
of a specific type on the other side of the Atlantic, the smaller fry and the dignitaries. ${ }^{\mathbf{1 4}}$

Here we have the Whig formula and also the reverse of Hutchinson's opinion of the agitators. Just as he felt that the firebrands flattered the populace and incited the crowds for the sake of personal popularity and power, Mercy Warren was convinced that the officials of England not only sold the King their services for a mess of pottage, but impressed on his mind hostility towards the colonies. They made the colonies lose their patience and filled the bitter cup to overflowing, disregarding the social compact, the principles of justice and humanity. The connection with Britain had to be broken off.

Thus, in her narrower interpretation Mercy Warren, very similarly to Hutchinson, the man so thoroughly hated, places her emphasis on the action of politicians. Only the actors are different in the two instances. Historians generally believe that Mercy Warren explains the matter very simply and gives rise to the Whig interpretation of the Revolution. ${ }^{15}$

The same was to be said of the 19th century historian George Bancroft (when the great revision set in at the turn of that century.)

The formula was understood to be that if the good whigs had been in power rather than the bad King and his ministers, England would not have lost her colonies, at least not in such a way, through a bloody war. And to some extent the critics were right.

It need not be added that the doggedness of Mrs. Warren's opinions, her descriptions of the King's character and policy, of the influence of the Bute, of the Machiavellian Hutchinson, the corrupt parliament, colonial servants and all, sound a bit crude at present.

Yet it should be remembered that the language of Mrs. Warren, turned to a solemn mood, seems to be borrowed alive from the Revolutionary proclamation, and it also foreshadows the style of the 19th century. John Adams, a rationalist, disliked that enthusiasm not only for the outward form, but also for its spirit of Jeffersonian

${ }^{14}$ Ibid. pp. $22 \mathrm{ff}$.

15 Merrill Jensen, »The Interpretation of the American Revolution,) $>$ Paper read at the Amer. Hist. Assoc. annual meeting in 1955 (mimeographed copy), p. 4. Also numerous other historians. 
Republicanism. ${ }^{16}$ Mrs. Warren belonged to the group of Republican patriots who somewhat later would be called radicals. It is no coincidence that she speaks of liberty and equality in whose pursuit the downtrodden fled from old world to the new and that she uses the words of Thomas Paine. But perhaps her exalted speech is actually not artificial because it expresses her candid feelings. Unlike the sphiliopietistic» historians of somewhat later time, to whom their nation would always be right, she could see her people both in the right and in the wrong. Her high-flown terms make the present-day reader smile, but she writes with striking integrity, good-will and also the indignation of the reformer. She accused the well-to-do of pursuing their private interests, of breaking the rules of non-consumption; she condemned speculation that enriched the unprincipled to the injury of ordinary people; she praised the equalitarian North and - like Abigail Adarns - disapproved of slavery.$^{17}$ She stressed the popular character of the Colonial Army.

In the spirit of Paine and of Jefferson, she speaks with sympathy of the abolition of monarchy in France. And here, together with her general picture of the Revolution, we reach the second, the broader part of her interpretation. The excesses of the French Revolution horrified her. She says: $\gg$ These revolutionary scenes in every nation are generally attended by circumstances shocking to the feelings of compassion, yet undoubtedly all nations have right to establish such modes and forms of government as a majority shall think most conducive to the general interest. ${ }^{18}$ She writes also about the partitions of Poland, speaks kindly and with respect about Kościuszke, fighter for American independence and later for the freedom of his own country as well as its democratic reform. ${ }^{19}$

There are pertinent parallels and attempts at generalization in the sinterspersed observations>, of Mercy Warren. As a forerunner of American Romanticism she has bent both for nationalism and universalism, she also voices liberty and democratic ideas. The »narrower» interpretation does not exhaust her views. It would be too simple. If we conceive the »Whig interpretation., in the

${ }^{16}$ M. Kraus, op. cit. p. 79.

${ }^{17}$ Mercy Warren, op. cit. I, 22, 69-71; II, 235-236, 366 ff., III, 372 ff.

${ }^{18}$ Ibid. III, 379-380.

${ }_{10}$ Ibid. II, 183-186; III, 182. 
wider sense of liberal Anglo-Saxon tradition, then we can see Mercy Warren's History within that frame, Mercy Warren had broad enough horizons to detect some of the deeper roots of the upheaval and to embrace a good deal of the outside world, although she seems to have never left the borders of Massachusetts but she does imply that the American Revalution was a link in the struggle for freedom cutting through national boundaries in the second half of the 18 th century.

Soon after Mercy Warren's book was published there ensued a correspondence with John Adams which threw light on several questions of detail and general meaning. As in the case of many another book, the first histories of the Revolution had their own histories. Habent su a f a $1 \mathrm{ibe} 11 \mathrm{y}$.

The well-known works of William (Gordon and David Ramsay had also their later fates: at the turn of the 19th century an American scholar, Orin Grant Libby, accused both of them, and several others, of plagiarism with regard to the English »Annual Register, For a long time their books were not quoted. However, not the whole of their works is tainted with plagiarism. They also belong without doubt to the pre-American or anti-British trend of a moderate character and therefore mark — as I believe - the beginning of an important current in the historiography of the American Revolution. Today quite a few American scholars are restoring their value, Merril Jensen and Arthur M. Schlesinger, Sr. are certainly excellent experts in the Revolutionary era. Also Evarts B. Greene or Clinton Ressiter quote Ramsay.

The historian chosen here for discussion is David Ramsay who was a direct participant of the Revolution. What Orin Grant Libby said about Ramsay some 70 years ago may be to some extent correct if we adopt scholarly standards binding at a considerably later time than the corresponding customs current at the turn of the 18th century. But even if we applied these standards more rigidly than we probably should, Libby's charge would hold with regard to the descriptions of military events. English parliamentary debates so exhaustively reproduced by the »Annual Register,, and certain excerpts from or summaries of official documents (as given by the Chronicle). The examples of plagiarism presented by Libby are taken from latter parts of Ramsay's work. They do not apply to 
the first $120-13 \mathrm{Q}$ pages of the last volume in which Ramsay discusses the origin of the movement for independence. ${ }^{20}$ We can also observe a considerable difference in the treatment of the Declaration of Independence by Ramsay, a Republican and American soldier of the Revolution, and the English chronicler, a Whig - whether he was Edmund Burke or not - but a monarchist and man who regretted the loss of the colonies.

A point no historians seem to have noticed is to be found in the Annual Register for 1776 under the date of July 4th: four sentences on the fact that the Americans declared independence, sentences inserted in a detailed description of the course of hostilities of that summer. We can read that the Declaration was a sad consequence of England's excessive jealousy of power and of the colonies' neglect of obedience. We learn also that it was a long list of pretensions with a great deal of invective, whereupon the author takes up again the interrupted narrative of the military campaign. ${ }^{21}$ Such an attitude of the English chronicler who was not a Price or a Priestly is quite understandable. It is equally understandable that Ramsay should have a different approach. He does not interrupt his narrative of hostilities, but instead discusses the Declaration at length at another place, in a separate chapter (the last one of his last volume) devoted to political matters: independence, state constitutions, and the Confederation. ${ }^{22}$

To tell how the Declaration was born Ramsay uses eight pages, then he quotes its text in full and adds:

${ }^{20}$ Concerning the charge of plagiarism against Gordon and Ramsay, H. L. Gipson writes in his historiogtaphical survey (The British Empire befove the American Revolution, V. XIII, New York 1967, p. 324): »A constant problem faces the scholar dealing with writings in this early period of British and American historiography; it involves the question of who borrows from whom and the ethics of borrowing. Take, for example, the Annual Xegistev. When Edmund Burke or someone else prepared the material for this monthly publication the sources of his information were seldom disclosed and results of his compilation were therefore doubtless considered common property and were used as such.» Professor Gipson goes on to say that Libby's first citation does not occur until page 379 of Gordon's history. The present author - not knowing Gipson's work on the British Empire - noticed something very similar with regard to Ramsay: Libby's first citation refers to $p 124$ of Ramsay's I vol. It could be added that quotations from the Annual Register (of that period), even if very frequent, are not generally questioned as to their veracity, in our times, provided the source is given. See Simon Maccoby in his English Radicalism 1762-1785 (London 1955).

${ }_{21}$ Annual Register for 1776 (publ. 1788), p. 165.

22 David Ramsay, History of the American Revolution, London 1793, Ch. XIII, v. I, pp. 332-357. 
»The genius of the American, their republican habits and sentiments, naturally led them to substitute the majesty of the people in lieu of discarded royalty $\gg^{23}$

Some such statements of his are taken up today. Professor Jensen points out that Ramsay is »more sophisticated, than Mercy Warren, especially in showing the economic power of the colonies on the eve of their insurrection against England. Thus he writes in the above cited papers: "Ramsay offers interpretations that are either still being debated or have been offered as new discoveries by latter day historians>,.

A few marks will be added here concerning the first, which I would call the »free» or »clean» part of Ramsay's work. They are not intended to renew the charge of plagiarism, but are rather an attempt to find out in what the value of Ramsay consists. I have in mind mostly that first »untainted» part, in which he speaks of the origin and character of the Revolution.

There is in that part of the book an exposition concerning the American character and society not mentioned by Libby and, as it seems not noticed by other American critics. It is a rather faithful reminiscence of thoughts contained not in the Annual Register but in the famous speech of Edmund Burke on Conciliation with the colonies held in Parliament in March 1775. To recall the causes of American attachment to freedom as given by Burke: the tradition of English constitutional liberties which under local conditions contributed to the rise of broad self-government and provincial legislatures; the most radical dissent, a protest against protestantism; widespread education; good knowledge of law and the ability to defend one's legal claims - or the attorney's aptitude for pleading a cause; the pride jealously treasured personal liberty peculiar to the slaveowning South (he compared this with the character of Polish nobility who owned serfs); finally America's distance from the mother country which naturally weakens the cohesion of any big empire.

Burke presented the factual state of affairs to be reckoned with (probably a number of his arguments were known and used before) and warned that forcing the colonies through violence to submission

${ }^{23}$ Ibid. p. 349. 
would have the opposite effect and provoke them to revolt - to fling $\gg$ Brittish sovereignity in their teeth» - as he said.

Burke's speech was widely distributed and known in the colonies. As Ramsay reproduces or rather recreates it, he does it in his own words, repeating in the almost exact phrasing only two sentences of the British statesman which every educated American interested in politics probably knew by heart at the time. We do not know if Ramsay was even aware that he repeated the opinions of Burke, but he agreed with them (and made them his own). The present-day reader may also, with rather few reservations, agree with these statements.

In this connection it should be brought out what Ramsay adds to Burke's »causes» of American discontent, presenting them as the antecedents of independence. Hc dwells at some length on the differences dividing colonial society from the British: the absence of feudalism, majority of farmers among the population, on the whole socially equal, not too wealthy and not too poor. Work, lack of luxuries, modest welfare - these were the features of the colonists' lives and their virtues, with the exception, of course, of the plantation south, where slavery hurts the dignity of labour and diminishes its output, breeds laziness among the whites, corrupts morals, hinders progress. These vices of the South are repaired not only by New England or Pennsylvania, but also by the West with its dominating small free farmning, writes Ramsay. He draws matterof-factly a picture of stratified society, no Arcadia, and he also speaks of the wrongs inflicted on the Indians.

He stresses the character of the average independent farmer as the dominant trait of colonial men and society. Thanks to the existence of big unpopulated stretches of land the colonist could easily acquire his own farming plot and be his own master, unhampered by the dense network of legal regulations in which his brothers were entangled in the Old World. Personal liberty fostered the love of political independence. The general similarity of conditions and occupation created a feeling of equality and common bonds between the colonies. Distance, not only in space as Burke adduced it, but also in time, several generations born in America, ignorance of what Britain was like - all of this removed the colonists mentally and sentimentally from the mother country. And so he goes on in this 
vein, mentioning also the remoteness from European mutual quarrels and wars, and relative freedom from the passions and follies of rulers.

Such is the canvass dressed by Ramsay to show the roots of independence $^{\mathrm{Z} 4}$ (how it came about, the role of consciousness, political leaders and propaganda is another matter which he dos not omit). The above remarks are not too original: apart from Burke we may find some of them in the writings of Jefferson, others in the works of Franklin, St. John de Crevecoeur or Thomas Paine. They are repeated by a host of minor writers (and we may also find many of them today as the result of minute research by sociological-historical method). The watchword to keep away from European disputes and wars contained in »Common Sense,, is known to have become the major principle of American foreign policy prescribed by George Washington.

Ramsay asserts that the colonists had not grumbled very much over the trade and navigation laws before 1764, that they had been well off, that some regulations had been often and freely evaded and others not felt to be unduly harmful. More or less like the Old Whigs, he believed that England had been wise in her policy when granting their colonies broad liberty and not interfering too much (the salutary neglect of Walpole). He compared it with the colonial policy of other powers in their disfavour. To such comparisons American historians would return in the first decades of the 20th century (especially Claud Hedstead Van Tyne, 1922).

Only the new restrictions, their sudden and intense character provoked resistance. If to the causes of grudge existing in 1763 no new provisions had been added, the discontent would not have been great. This sounds modern indeed.

Ramsey is consistent. If the colonies were well off and enjoyed broad political liberty, then they could not groan under the yoke of oppression. On the contrary, the colonies developed during their attachment to the British empire, but within the frames of an autonomy not much short of independence.

Under the favourable conditions of the New World the colonies had achieved almost the strength and greatness of a separate nation.

${ }^{24}$ Ibid $_{\text {. pp. }} 30 \mathrm{ff}$. 
At the critical moment - the close of the French and Indian War and the cession of Canada - came the turn of the tide. It was then that the mutual relations between the colonies and motherland changed. The economy of America, says Ramsay, flushed like a river overflowing its banks, and when it was further stemmed by new and sharper restrictions, it started violently to break through the clams. The new policy of England was felt by the colonies as the jealousy of an evilhearted stepmother (this was a current expression and general feeling of the times). "The remedy for smuggling and other breach of English law proved worse than the disease.

»It was natural for Great Britain,)) he writes »to wish for an extension of her authority over the Colonies, and equally for them, on their approach to maturity, to be more impatient of subordination, and to resist every innovation for increasing the degree of their independendence». ${ }^{25}$

He does not meditate over the charge of illegal and early striving for independence. He does not split hairs over questions of law but treats them with the realism of - a doctor.

Thus the constitutional argument so deeply absorbing the antagonists of the times, so important, to Hutchinson, and later to the historians for a 150 years down to the 20th century, was looked upon by Ramsay with the eye of a practical man and observer. By profession a physician, born in Pennsylvania, he settled down in South Carolina, rreated the sick, but soon became a member of the provincial assembly. During the war he was a British prisoner for a time, and later member of the Continental Congress. The American cause was his own. From his participation in the conflict he gained many a direct experience. He was able to use it and keep at the same time an open mind. If we say that among the leaders who were also observers, it was Benjamin Franklin who possessed a similar capacity to look at things - without comparing the depth of thought and elegance of style of the great scholar and philosopherstatesman with our historian - this will be only a compliment to Rarnsay.

Ramsay attempts also to reply to the question of how the common readiness to fight arose among the colonies. The blows of

${ }^{25}$ Ibid. p. 44. 
1765 and 1767 hit all the colonies. The third stroke of 1774, however, affected one colony, Massachusetts, directly, and concerned the other ones only indirectly. But the fate of Boston and Massachusetts threatened all of them if not today - then tomorrow. The threat had to be explained to the colonists; they had to be persuaded to defend Boston, to rise against the danger of forfeiting their own liberties, in spite of the circumstances that in $1773-74$ they had still been - as Ramsay says - happy. That important task was fullfilled by organization and propaganda. In this connection Ramsay expresses a similar thought we have observed in Hutchinson's book about 1773 - 74 the colonists rose in action not so much under the influence of existing pressure as in fear of future evil. But Ramsay regards the danger as a real one; whereas to Hutchinson it was imaginary. ${ }^{26}$ Ramsay draws attention to the great significance of the committees of correspondence, which in his opinion (not dissimilar from the view of John Adams expressed in a letter to Mably) had grown from the traditions and experience of town meetings and other organs of local self-government.

Ramsay is not passionate but he is not cold either. He speaks with sympathy of the sufferings of people during the war - of both belligerent parties. There is no hatred of the mother country in Ramsay nor contempt of her King and ministers. There is not even the proverbial restraint and selfcontrol concealing repugnance. Like both rationalists and humanists of his age, he is a »friend of the human race,» he wants to - understand. One only wonders how a fighter would afford such a lanced judgement. Hutchinson's work has seen the praises of many historians for the author's self-restraint and impartiality. The impartiality of Ramsay is at least as striking, if we consider that he was .equally engaged in his cause as Hutchinson in his - only on the other side, on the side of freedom.

As a fighter and leader Ramsay could not underestimate the role of politics in the Anglo-American conflict. But in his considerations

${ }^{26}$ See Merrill Jensen, p. 4 of the paper quoted above, and The Reinterpretation of Early American History, Essays in honor of Jahn Edwin Pomfret, San Marino, Cal., 1966, pp. 108, 112 (the latter not known to the present author before conclusion of her study). Professor Jensen stresses the similarity of the loyalists' and Ramsay's approach to the role of leadership and the assumption that the bulk of people were indifferent to independence (hence the necessity and significance of propaganda). That seems to be a somewhat different line of thought than the nresent author's. See infra. 
upon the origin of the American Revolution it does not rank first. It it true that Ramsay saw the possibility of a compromise, but not too much of it. He regretted that it had to come to an armed conflict and that it took so many victims, but he did prefer an independent America and a republic to the connection with monarchical Britain. His peculiar trait was what at a later date would be called American pragmatism, a not the Common Sense of a Tom Paine, fervent, coloured with hatred of England and monarchy and full of ardent love of the people and freedom. It was the everyday practical sense coloured with dislike of aristocracy, kindness for people and attachment to civil liberties. This makes also Ramsay different from Mrs. Warren.

Thus, roughly speaking, it may be said that greater emphasis is placed on politics and the action of men (or leaders) by loyalist historians like Hutchinson, and patriots like Mercy Warren. It also seems that the same authors concentrate on the questions of right and wrong - which does not mean that the patriot-historian Mercy Warren does not see the broad background of the Revolution, its connection with general history, its democratic character.

Ramsay - whom I should like to call a historian of the smiddle course» - looks first for the real things that happened and then presents and passes his judgement on policy. He does not voice general opinions on history as does Mrs. Warren (though he was the author of a general history).

His attempts to explain the events of $1763-1776$, and the way he explains them against the background of earlier developments, result in the fact that he attaches importance to general conditions and changes which today we might refer to as historical processes. He does not say that the breach of the colonies with the mother country was inevitable. The wise eclectic Ramsay simply states the fact that the American colonies attained to $»$ the magnitude of a nation».

This is an abbreviated chapter of a study on $\gg$ The Origin arid Character of the American Revolution: English and American Historical Interpretations of the 18th and the 19th Centuries», written in Poland and finished in 1967. The present short version was read at a seminar at the Historical Department of the University of Jerusalem in February 1970. 